\title{
NUWT: JAWI-SPECIFIC BUCKWALTER CORPUS FOR MALAY WORD TOKENIZATION
}

\author{
${ }^{1}$ Juhaida Abu Bakar, ${ }^{2}$ Khairuddin Omar , ${ }^{2}$ Mohammad Faidzul \\ Nasrudin \& ${ }^{2}$ Mohd Zamri Murah \\ ${ }^{1}$ Universiti Utara Malaysia, Malaysia \\ ${ }^{2}$ Universiti Kebangsaan Malaysia, Malaysia
}

juhaida.ab@uum.edu.my;ko@ukm.edu.my;mfn@ukm.edu.my; zamri@ukm.edu.my

\begin{abstract}
This paper describes the design and creation of a monolingual parallel corpus for the Malay language written in Jawi. This paper proposes a new corpus called the National University of Malaysia Word Tokenization (NUWT) corpora To the best of our knowledge, currently, there is no sufficiently comprehensive, well-designed standard corpus that is annotated and made available for the public for the Jawi script corpora. This corpus contains the Jawi-specific Buckwalter character code and can be used to evaluate the performance of word tokenization tasks, as well as further language processing. The objective of this work is to conform and standardize the corpora between similar characters in Jawi. It consists of three subcorporas with documents from different genres. The gathering and processing steps, as well as the definition of several evaluation tasks regarding the use of these corpora, are included in this paper. One of the important roles and fundamental tasks of the corpus, which is the tokenization, is also presented in this paper. The development of the Malay language tokenizer is based on the syntactic data compatibility of Malay words written in Jawi. A series of experiments were performed to validate the corpus and to fulfill the requirement of the Jawi script tokenizer with an average error rate of 0.020255 . Based on this promising result, the token will be used for the disambiguation and unknown word resolution, such as out-ofvocabulary $(\mathrm{OOV})$ problem in the tagging process.
\end{abstract}

Keywords: Malay corpora, word tokenization, regular expression, Buckwalter character code. 


\section{INTRODUCTION}

The annotated corpora, the Malay corpus (Knowles \& Don, 2003) and the Dewan Bahasa dan Pustaka (DBP) database (DBP, 2015) corpora, are among the most valuable resources in current natural language processing in Malay studies. They underlie statistical research in monolingual tasks, such as sentence structure, syntactic disambiguation, semantic recognition, information retrieval, etc. Annotated corpora constitutes a very useful tool for research.

The Malay language consists of two writing systems. The Malay language is usually written in Roman (Rumi), which stands for the Latin alphabet, and also written in Jawi, which is originally from the Arabic language. Some efforts are currently being undertaken to strengthen Jawi writing among the Malays in Malaysia. For the Malaysian Malay community, the creation of a monolingual parallel corpus between Roman and Jawi has a special significance. It provides the basis for the development of Malay language applications that can be used to facilitate or even avoid labor and time-consuming processes of manual handling of parallel language information. In addition, such a corpus enables the empowerment of minority languages. With the use of a monolingual parallel corpus and the methods which allow for the transfer of linguistic annotations across parallel languages, new resources and tools can be created for the minority languages.

The goal of the research as presented in this paper is for the development of a parallel language corpus and basic tools and resources for the Malay language. This paper describes the creation of such parallel corpus and the attachment of a part-of-speech (POS) tagset for the Malay corpus. The pattern of the Malay language is quite different from Indo-European languages because of its lower level. At high syntactic level, the language is similar enough to Indo-European language, and one can talk of direct objects in transitive constructions and even of agentless passive. The dominant sentence order is SVO (Knowles \& Don, 2003).

Several collections of unannotated Jawi texts do exist. However, the only corpus with incorporated linguistic information that is currently available for the Malay language is a small corpus of approximately 30,500 tokens annotated with POS analyses. The Malay corpus written in Rumi are the Malay corpus (Mohamed, Omar, \& Ab Aziz, 2011) and the Malay Corpus UKM-DBP (Saad, Bakar, Karim, Tukiman, \& Nor, 2012). For the attachment of the POS tagset to a new parallel corpus, an original tagset applied in Mohamed et al. (2011) 
and Saad et al. (2012) is used. To evaluate the new corpus, a pilot test was conducted on word tokenization, which is the first step of any kind of natural language text preparation.

\section{LITERATURE REVIEW}

In this section, an overview is given on related corpora, such as the English, Arabic and Austronesian corpus. The Natural Language ToolKit (NLTK) provides convenient ways to access several of the English corpora, with more than 38 corpora listed in the NLTK Data (NLTK Project, 2015). The NLTK provides many text corpora which contain linguistic annotations representing prosodic, part-of-speech tags, named entities, syntactic structures, semantic roles, etc. Table 1 sums up related corpora by giving a comparison between all these corpora.

Table 1

Comparison between Corpus

\begin{tabular}{|c|c|c|c|c|}
\hline Corpus & Corpus Type & Language & Content & Availability \\
\hline Brown Corpus & $\begin{array}{l}\text { Grammatical } \\
\text { corpus }\end{array}$ & English & $\begin{array}{l}1.15 \text { million words, } \\
\text { tagged and categorized } \\
15 \text { genres }\end{array}$ & Public \\
\hline Penn Treebank & $\begin{array}{l}\text { Grammatical } \\
\text { corpus }\end{array}$ & English & $\begin{array}{l}40,000 \text { words, tagged and } \\
\text { parsed }\end{array}$ & $\begin{array}{l}\text { Public } \\
\text { (selection) }\end{array}$ \\
\hline $\begin{array}{l}\text { CMU Pronouncing } \\
\text { Dictionary }\end{array}$ & Prosodic corpus & English & $\begin{array}{l}100,000 \text { words and } \\
\text { transcriptions }\end{array}$ & Public \\
\hline WordNet 3.0 & WordNet & English & 145,000 synonym sets & Public \\
\hline $\begin{array}{l}\text { Quranic Arabic } \\
\text { Corpus (Dukes \& } \\
\text { Habash, 2010) }\end{array}$ & $\begin{array}{l}\text { Syntactic and } \\
\text { morphological } \\
\text { Quran corpus }\end{array}$ & $\begin{array}{l}\text { Arabic } \\
\text { (Arabic } \\
\text { Buckwalter } \\
\text { code) }\end{array}$ & $\begin{array}{l}\text { Builds on the verified } \\
\text { Arabic text distributed by } \\
\text { the Tanzil project }\end{array}$ & Public \\
\hline $\begin{array}{l}\text { SEAlang Library } \\
\text { Malay Text Corpus } \\
\text { ("SEAlang Projects," } \\
\text { 2011) }\end{array}$ & $\begin{array}{l}\text { Monolingual } \\
\text { corpus }\end{array}$ & $\begin{array}{l}\text { Malay } \\
\text { (Roman) }\end{array}$ & $\begin{array}{l}\text { Consists of Malay texts } \\
\text { retrieved from a variety } \\
\text { of Internet sources }\end{array}$ & Proprietary \\
\hline WordNet Bahasa & WordNet & $\begin{array}{l}\text { Malay } \\
\text { (Roman) }\end{array}$ & $\begin{array}{l}\text { Malay semantic } \\
\text { dictionary (Malaysian } \\
\text { and Indonesian) }\end{array}$ & Proprietary \\
\hline $\begin{array}{l}\text { Quranic Malay written } \\
\text { in Jawi character } \\
\text { Corpus (Sulaiman, } \\
\text { 2013) }\end{array}$ & $\begin{array}{l}\text { Monolingual } \\
\text { unannotated } \\
\text { corpus }\end{array}$ & Malay (Jawi) & 157,388 words & Upon request \\
\hline
\end{tabular}

(continued) 


\begin{tabular}{|c|c|c|c|c|}
\hline Corpus & Corpus Type & Language & Content & Availability \\
\hline $\begin{array}{l}\text { Malay corpus } \\
\text { (Mohamed et al., } \\
\text { 2011) }\end{array}$ & $\begin{array}{c}\text { Grammatical } \\
\text { corpus }\end{array}$ & $\begin{array}{l}\text { Malay } \\
\text { (Roman) }\end{array}$ & 18,135 tokens & Upon request \\
\hline $\begin{array}{l}\text { Malay corpus UKM- } \\
\text { DBP (Saad et al., } \\
\text { 2012) }\end{array}$ & $\begin{array}{l}\text { Grammatical } \\
\text { corpus }\end{array}$ & $\begin{array}{l}\text { Malay } \\
\text { (Roman) }\end{array}$ & 12,304 words & Upon request \\
\hline NUWT Corpus & $\begin{array}{l}\text { Grammatical } \\
\text { literary corpus }\end{array}$ & $\begin{array}{c}\text { Malay (Jawi- } \\
\text { specific } \\
\text { Buckwalter) }\end{array}$ & 187,827 words & $\begin{array}{c}\text { Commercial } \\
\text { market }\end{array}$ \\
\hline
\end{tabular}

Unannotated Jawi corpus has been developed from a variety of sources, including old Jawi manuscripts, Al-Quran text translation, textbooks and local newspapers. Research on Jawi is widely used in the learning field, for instance in Multimedia (MM), computer hardware, such as virtual keyboard (Engineering) and in the field of Artificial Intelligence in the study of Pattern Recognition (PR), Natural Language Processing (NLP) and Machine Learning (ML). In the study of PR, a Jawi script undergoes the process of character recognition in handwritten or printed form. Segmentation deals with the identification of the Jawi characters. Then, the characters are dealt with in the processes of NLP and ML field at the final part. Previous studies related to Jawi include the research on MM (Diah, Ismail, Ahmad, \& Abdullah, 2010; Diah, Ismail, Hami, \& Ahmad, 2011); Engineering (Ismail, Yusof, \& Jomhari, 2010); PR (Azmi, 2013; Heryanto, Nasrudin, \& Omar, 2008; Redika, Omar, \& Nasrudin, 2008); and NLP (C. W. S. B. C. W. Ahmad, Omar, Nasrudin, Murah, \& Azmi, 2013; Sulaiman, 2013), just to name a few. Figure 1 shows the trend of the studies conducted on the Jawi script.

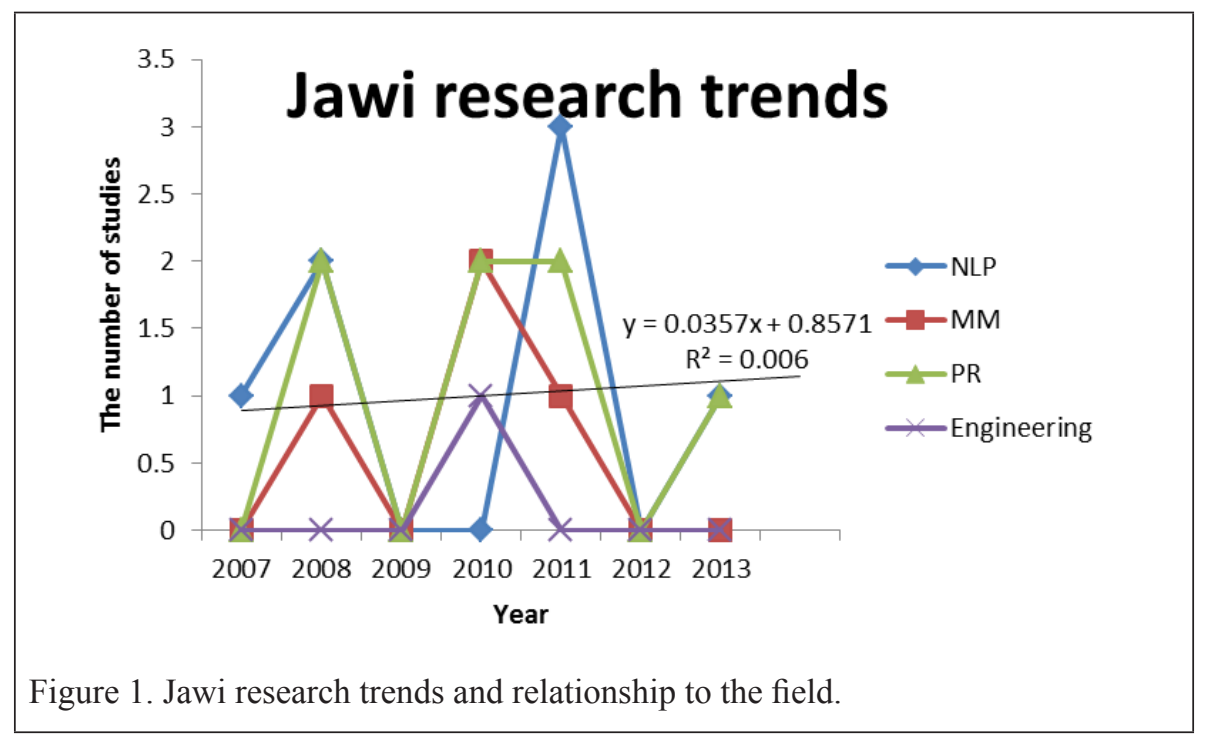


The corpus development of the Jawi script starts from the use of the POS tagset. For the Malay language written in Roman, a number of researches pioneered by linguists and computing researchers have developed a POS tagset corpus in justification of their research. Atwell (2008) states that before we develop a POS tagset, or decide to re-use an existing pos-tagset, we should be clear about why we want to pos-tag the corpus. For developers of corpus resources for general purposes, the aim is perhaps to enrich the text with linguistic analyses to maximize the potential for corpus re-use in a wide range of applications. On the other hand, very fine-grained distinctions may cause problems for automatic tagging if some words can change the grammatical tag depending on the function and context. At present, POS tagset for Jawi is no longer being developed. In order to do that, we believe that the corpus development of the Jawi script can facilitate the task of analyzing the NLP task pipeline for the Malay language written in Jawi. In the next section, the detailed description of the new corpus, namely the NUWT corpora, its corresponding collection, its acquisition processes as well as its structure, is given.

\section{NUWT CORPORA DESCRIPTION}

The NUWT corpora sources were gathered from three different genres of documents. The "Quranic Malay written in Jawi character Corpus" (Sulaiman, Omar, Omar, Murah, \& Rahman, 2011) is an unannotated text of the Quran translation and contains a collection of 114 chapters with 157,388 words. The corpus was used on the NLP task, Stemmer for Jawi characters, using two sets of rules in Jawi. One set of rules was used to stem various forms of derived words, while the other set was used to replace the use of a dictionary by producing the root word for each derivative.

The second source is an annotated corpus named the "Malay corpus" and contains 18,135 tokens with 1,381 words that have ambiguous tags. The corpora was prepared by Mohamed et al. (2011) using the Dewan Bahasa dan Pustaka (DBP) tagset. The DBP tagset was used because it is the highest government authorized body concerning Bahasa Malaysia and the grammar follows that of Bahasa Malaysia. The "Malay corpus" was written using Roman (Rumi) writing and has 21 tags, as shown in Table 2.

The third source corpus is a grammatical corpus named the "Malay corpus UKM-DBP". It is retrieved from Saad et al. (2012) and is a collection of newspapers, magazines and books with 12,304 words. The corpus was developed according to the DBP tagset and written using Roman writing. It has five main tags, with the elaboration fraction for each main tag shown in Table 3. 
Table 2

Malay Tagset DBP in Malay Corpus

\begin{tabular}{|c|c|c|c|}
\hline Tagset & $\begin{array}{l}\text { Description } \\
\text { in Malay }\end{array}$ & $\begin{array}{l}\text { Description } \\
\text { in English }\end{array}$ & Example \\
\hline $\mathrm{KN}$ & Kata Nama & Noun & meja/table, kerusi/chair \\
\hline KK & Kata Kerja & Verb & makan/eat, tidur/sleep \\
\hline ADJ & Kata Adjektif & Adjective & hitam/black, cantik/beautiful, dalam/deep \\
\hline KSN & Kata Sendi Nama & Preposition & $\begin{array}{l}\mathrm{di} / \text { at/on/in, } \mathrm{ke} / \text { to, dari/from, kepada/to/ } \\
\text { towards/at, dalam/in }\end{array}$ \\
\hline $\mathrm{KB}$ & Kata Bantu & Auxiliary verb & $\begin{array}{l}\text { akan/will/shall, belum/not yet, boleh/can/ } \\
\text { may, telah/already }\end{array}$ \\
\hline KG & Kata Ganti Nama & Pronoun & saya/I/me, awak/you \\
\hline $\mathrm{KH}$ & Kata Hubung & Conjunction & yang/null, dan/and, atau/or \\
\hline ADV & Kata Adverba & Adverb & $\begin{array}{l}\text { bahawasanya/in fact/truly, barangkali/may } \\
\text { be/probably }\end{array}$ \\
\hline KT & Kata Tanya & Question & $\begin{array}{l}\text { apa/what, berapa/how much/how many, } \\
\text { mengapa/why }\end{array}$ \\
\hline KBIL & Kata Bilangan & Cardinal & satu/one, dua/two \\
\hline KPM & Kata Pemeri & Narrator & adalah/is/are, ialah/is/are \\
\hline KP & Kata Perintah & Command & jangan/don't, sila/please \\
\hline KAR & Kata Arah & Direction & dalam/inside, atas/on top, bawah/under \\
\hline PW & Penanda Wacana & Discourse mark & hatta/then, maka/thus \\
\hline KEP & Kata Kependekan & Short form & UNCR, PBB \\
\hline$\# \mathrm{E}$ & Klitik-lah & Clitic lah & cubalah/please try \\
\hline @ $\mathrm{KG}$ & Klitik-nya & Clitic nya & bukunya/his book \\
\hline KNF & Kata Nafi & Deny & tidak/no, bukan/not \\
\hline KNK & Kata Nama Khas & Proper noun & Abdullah Badawi \\
\hline SEN & Senarai nombor & List number & (i), (ii), (iii), etc \\
\hline SYM & $\begin{array}{l}\text { Simbol atau tanda } \\
\text { baca }\end{array}$ & $\begin{array}{l}\text { Any symbol or } \\
\text { punctuations }\end{array}$ &.,$"$ - + etc \\
\hline
\end{tabular}

Source: Mohamed et al. (2011) 
Table 3.

Malay DBP Tagset in the Malay UKM-DBP Corpus

\begin{tabular}{lcccc}
\hline Tagset & $\begin{array}{c}\text { Description } \\
\text { in Malay }\end{array}$ & $\begin{array}{c}\text { Description } \\
\text { in English }\end{array}$ & $\begin{array}{c}\text { Detailed Description } \\
\text { in Malay }\end{array}$ & $\begin{array}{c}\text { Detailed Description } \\
\text { in English }\end{array}$ \\
\hline NAK & Kata Nama & Noun & Kata Nama Am Konkrit & Concrete Noun \\
NAA & & & $\begin{array}{c}\text { Kata Nama Am Abstrak } \\
\text { Kata Nama Khas Konkrit }\end{array}$ & $\begin{array}{c}\text { Abstract Noun } \\
\text { Concrete Proper Noun }\end{array}$ \\
NKK & & & Kata Nama Khas Abstrak & $\begin{array}{c}\text { Abstract Proper Noun } \\
\text { NKA }\end{array}$ \\
VT & Kata Kerja & Verb & Kata Kerja Transitif & Transitive Verb \\
VTT & & & Kata Kerja Tak Transitif & Intransitive Verb \\
VB & & & Kata Kerja Bantu & Auxiliary verb \\
A & Kata Adjektif & Adjective & Kata Adjektif & Adjective \\
PR & Kata Preposisi & Preposition & Kata Preposisi & Preposition \\
G1 & Kata Ganti Nama & Pronoun & Kata Ganti Nama Pertama & Pronoun \#1 \\
G2 & & & Kata Ganti Nama Kedua & Pronoun \#2 \\
G3 & & & Kata Ganti Nama Ketiga & Pronoun \#3 \\
\hline
\end{tabular}

\section{NUWT CORPORA ANALYSIS}

Orthography is the main problem that has led to the development of the NUWT Corpora. Many NLP researchers have focused on Roman script (Abdullah, Hashim, \& Mohamed Husin, 2011; Mohamed et al., 2011; Noor, Noah, Aziz, \& Hamzah, 2010; Suhaimi Ab Rahman, Omar, \& Aziz, 2011; Suhaimi Ab Rahman, Omar, Mohamed, Juzaidin, \& Aziz, 2011; Suhaimi Abdul Rahman \& Omar, 2013); while just a few have focused on Jawi script (Abdul Ghani, Zakaria, \& Omar, 2009; Abu Bakar, 2008; C. W. S. B. C. W. Ahmad et al., 2013; C. W. S. C. W. Ahmad, 2007; Sulaiman, Omar, Omar, Murah, \& Abdul Rahman, 2014; Yonhendri, 2008). Figure 2 shows the original Jawi orthography from old manuscripts.

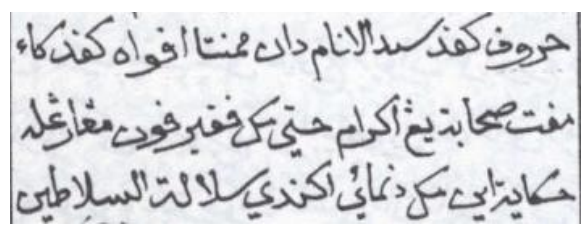

Figure 2. Original Jawi orthography 
Close orthography, such as the Arabic language, leads in such studies (Diab, Hacioglu, \& Jurafsky, 2004). Even though Jawi is similar to Arabic, Jawi has six more characters than Arabic. Jawi script also represents the Malay language, which is different from Malay (Roman). MADAMIRA is an Arabic morphology project by Pasha et al. (2014), which can be accessed at http:// nlp.ldeo.columbia.edu/madamira/. Figure 3 shows a sample input and Figure 4 shows the result of the tokenization and morphology from MADAMIRA. As shown, several additional characters have been changed to the equivalent similar orthography in Arabic.

\section{اوليه زاميله-هنيم دادا ن كليهنَن تورون ناءيق}

Figure 3. Jawi script sample input

$$
\text { اوليةه) زاميده - هشيم دادا (ن) كليهن ثورون ناعيق }
$$

Figure 4. MADAMIRA output process

However, the equivalent similar orthography represents another pronunciation sound of the word. The orthography issues are shown in Table 4.

Table 4.

Orthographic issues using MADAMIRA

\begin{tabular}{|c|c|c|c|}
\hline $\begin{array}{c}\text { Malay } \\
\text { Orthography }\end{array}$ & $\begin{array}{c}\text { Roman equivalent } \\
\text { sound }\end{array}$ & $\begin{array}{c}\text { Arabic } \\
\text { Orthography }\end{array}$ & $\begin{array}{c}\text { Roman equivalent } \\
\text { sound }\end{array}$ \\
\hline 。 & $\mathrm{h}$ & $\ddot{0}$ & $\mathrm{t} / \mathrm{h}$ \\
\hline ث & ny & ن ن & $\mathrm{n}$ \\
\hline ف & $\mathrm{v}$ & 9 & $\mathrm{w}, \mathrm{u}, \mathrm{o}$ \\
\hline$\ddot{\varepsilon}$ & ng & $\dot{\varepsilon}$ & gh \\
\hline ذَ & g & 5 & $\mathrm{k}$ \\
\hline ق & $\mathrm{p}$ & ف & $\mathrm{f}$ \\
\hline
\end{tabular}

\section{NUWT CORPORA DEVELOPMENT}

The NUWT corpora development goes through several phases, such as preprocessing or encoding phase, tokenization and corpus annotation. In the first phase, two encoding transliteration processes are carried out, which are the 
transliteration of Roman to Jawi and the transliteration of Jawi (Unicode) to Jawi (Buckwalter code). In this phase, both the Malay corpora (Malay corpus and Malay corpus UKM-DBP) are translated into Jawi using Teruja or Ejawi (Malay Text Rumi-To-Jawi Script Transliteration system), which can be accessed at http://www.jawi.ukm.my and http://www.ejawi.net/. After the transliteration process, the data is randomly checked using the Rumi-JawiUnicode dictionary for writing style and Unicode. Table 5 shows several errors detected using Teruja and Ejawi. The processed data is shown in Fig. 5.

\section{Table 5}

Errors after using the Online Transliteration System

\begin{tabular}{|c|c|}
\hline Error & Description \\
\hline Letters & 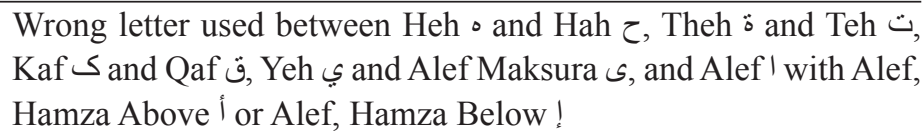 \\
\hline Loanword & $\begin{array}{l}\text { The suggested word is given but requires for a human expert to } \\
\text { check the spelling. }\end{array}$ \\
\hline $\begin{array}{l}\text { Variant positional } \\
\text { forms }\end{array}$ & $\begin{array}{l}\text { An Arabic representation form has variant positional forms, which } \\
\text { contains isolated, medial, initial and final forms. All Arabic texts } \\
\text { (including Jawi) follow Arabic representation form. In order to use } \\
\text { Jawi } \rightarrow \text { Buckwalter transliteration code, we only used Arabic letter } \\
\text { in the Arabic block (U+0600..U+06FF) or the Arabic Supplement } \\
\text { block }(\mathrm{U}+0750 . . \mathrm{U}+077 \mathrm{~F}) \text {. }\end{array}$ \\
\hline
\end{tabular}

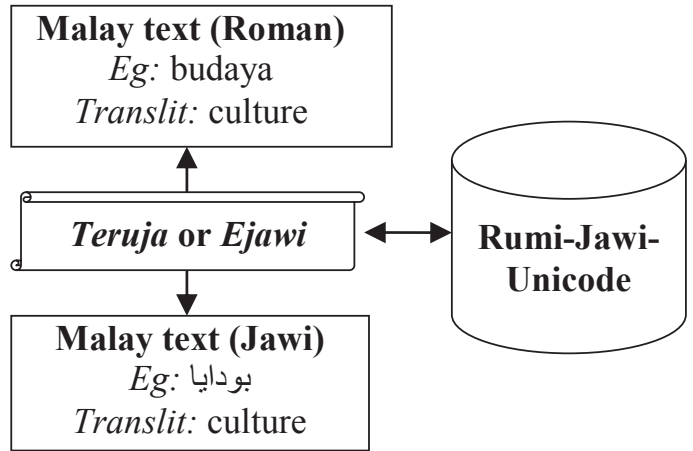

Figure 5. Pre-processing phase in preparing the data. 
In the second phase, the NUWT Corpora scripts are translated into Buckwalter transliteration. The Roman (Rumi) writing uses ASCII character code. Meanwhile, Jawi writing uses UNICODE character code ${ }^{1}$. Jawi script has 36 characters, consisting of 30 shared characters with the Arabic language and six newly created characters to meet the needs of Malay language phonemes. The six additional letters are ca $\approx$, nga $\dot{\xi}$, nya $\dot{\hat{H}}$, pa $\dot{\boldsymbol{\theta}}$, ga project, we used the Buckwalter transliteration to the Jawi corpora ${ }^{2}$, named NUWT Corpora.

The Buckwalter transliteration has been used in many publications in natural language processing (NLP) and in resources developed at the LDC (Habash, Soudi, \& Buckwalter, 2007). The main advantages of the Buckwalter transliteration are that it is a strict transliteration (i.e., one-to-one) and it is written in ASCII characters. Similar orthographic languages, such as Urdu (Habash \& Metsky, 2008) and Pakistani language (Irvine, Weese, \& CallisonBurch, 2012) also use Buckwalter transliteration. The extended Buckwalter transliteration applied to Jawi scripts is shown in Table 6 (Abdul Rahman, 1999; Unicode, 2014). The highlighted sections indicate those parts of the scheme that have been extended over the original scheme.

Table 6

The Positional Variant Forms of Jawi Characters with Unicode \& Buckwalter

\begin{tabular}{|c|c|c|c|c|c|c|c|c|c|c|c|c|}
\hline Letter & $\begin{array}{l}\text { Uni- } \\
\text { code } \\
(\mathbf{U}+)\end{array}$ & $\begin{array}{c}\text { Description } \\
\text { (Letter) }\end{array}$ & $\begin{array}{c}\text { Roman } \\
\text { equivalent }\end{array}$ & $\begin{array}{c}\text { Isolated } \\
\text { Form }\end{array}$ & $\begin{array}{l}\text { Uni- } \\
\text { code } \\
(\mathrm{U}+)\end{array}$ & $\begin{array}{l}\text { Initial } \\
\text { Form }\end{array}$ & $\begin{array}{l}\text { Uni- } \\
\text { code } \\
(\mathbf{U}+) \\
\end{array}$ & $\begin{array}{c}\text { Medial } \\
\text { Form }\end{array}$ & $\begin{array}{l}\text { Uni- } \\
\text { code } \\
(\mathbf{U}+)\end{array}$ & $\begin{array}{l}\text { Final } \\
\text { Form }\end{array}$ & $\begin{array}{l}\text { Uni- } \\
\text { code } \\
(\mathbf{U}+)\end{array}$ & $\begin{array}{l}\text { Buck- } \\
\text { walter }\end{array}$ \\
\hline 1 & 0627 & Alef & $\mathrm{a}$ & 1 & FE8D & & & & & 1 & FE8E & A \\
\hline ب & 0628 & Beh & $\mathrm{b}$ & بب & FE8F & ? & FE91 & : & FE92 & ب & FE90 & b \\
\hline : & 0629 & Teh Marbuta & $t / h$ & : & FE93 & & & & & $a$ & FE94 & $\mathrm{p}$ \\
\hline ت & $062 \mathrm{~A}$ & Teh & $\mathrm{t}$ & ت ت & FE95 & $j$ & FE97 & $\therefore$ & FE98 & $ت$ & FE96 & $\mathrm{t}$ \\
\hline 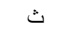 & 062B & Theh & $\mathrm{s}$, (th) & ث & FE99 & i & FE9B & 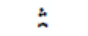 & FE9C & 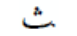 & FE9A & $\mathrm{v}$ \\
\hline ج & $062 \mathrm{C}$ & Jeem & $\mathrm{j}$ & ج & FE9D & $?$ & FE9F & $ج$ & FEA0 & ج & FE9E & $\mathrm{j}$ \\
\hline$\tau$ & 062D & Hah & $\mathrm{h},(\mathrm{h} \infty)$ & r & FEA1 & 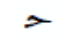 & FEA3 & $\approx$ & FEA4 & c & FEA2 & $\mathrm{H}$ \\
\hline ₹ & 0686 & Tcheh & $\mathrm{c}$ & 飞 & FB7A & जे & FB7C & خ & FB7D & 厄 & FB7B & $\mathrm{J}$ \\
\hline$\dot{\tau}$ & $062 \mathrm{E}$ & Khah & $\mathrm{kh}$ & $\dot{\tau}$ & FEA5 & $\dot{>}$ & FEA7 & $\dot{>}$ & FEA8 & $\dot{c}$ & FEA6 & $\mathrm{x}$ \\
\hline د & $062 \mathrm{~F}$ & Dal & d & 2 & FEA9 & & & & & $\lambda$ & FEAA & d \\
\hline$\dot{j}$ & 0630 & Thal & $\mathrm{z},(\mathrm{dh})$ & j & FEAB & & & & & $i$ & FEAC & * \\
\hline
\end{tabular}

http://unicode.org/charts/PDF/Unicode-7.0 (Range: 0600-06FF, FB50-FDFF, FE70-FEFF)

2 All Arabic script transliterations are provided in the Extended Buckwalter transliteration scheme (Bakar, Omar, Nasrudin, Murah, \& Ahmad, 2013). This scheme extends Buckwalter's transliteration scheme (Buckwalter, 2002) to increase its readability while maintaining the one-to-one correspondence with the orthography as represented in Unicode. For Jawi-specific extensions of the Arabic scripts, we extend the (Habash et al., 2007) transliteration scheme as follows:

$\mathrm{X} \dot{\mathrm{u}}, \mathrm{W} \dot{\mathrm{g}} \mathrm{e} \mathrm{e}, \mathrm{Q}, \mathrm{Q}$ 


\begin{tabular}{|c|c|c|c|c|c|c|c|c|c|c|c|c|}
\hline Letter & $\begin{array}{l}\text { Uni- } \\
\text { code } \\
(\mathrm{U}+) \\
\end{array}$ & $\begin{array}{c}\text { Description } \\
\text { (Letter) }\end{array}$ & $\begin{array}{c}\text { Roman } \\
\text { equivalent }\end{array}$ & $\begin{array}{c}\text { Isolated } \\
\text { Form }\end{array}$ & $\begin{array}{l}\text { Uni- } \\
\text { code } \\
(U+) \\
\end{array}$ & $\begin{array}{l}\text { Initial } \\
\text { Form }\end{array}$ & $\begin{array}{c}\text { Uni- } \\
\text { code } \\
(\mathrm{U}+) \\
\end{array}$ & $\begin{array}{c}\text { Medial } \\
\text { Form }\end{array}$ & $\begin{array}{l}\text { Uni- } \\
\text { code } \\
(\mathrm{U}+) \\
\end{array}$ & $\begin{array}{l}\text { Final } \\
\text { Form }\end{array}$ & $\begin{array}{l}\text { Uni- } \\
\text { code } \\
(\mathrm{U}+) \\
\end{array}$ & $\begin{array}{l}\text { Buck- } \\
\text { walter }\end{array}$ \\
\hline J & 0631 & Reh & $r$ & J & FEAD & & & & & J & FEAE & $\mathrm{r}$ \\
\hline j & 0632 & Zain & z & j & FEAF & & & & & j & FEB0 & $\mathrm{z}$ \\
\hline س & 0633 & Seen & $\mathrm{s}$ & س & FEB1 & سد & FEB3 & ميد & FEB4 & س & FEB2 & $\mathrm{s}$ \\
\hline ش ش & 0634 & Sheen & sy, (sh) & ش & FEB5 & ش & FEB7 & ش & FEB8 & ش ش & FEB6 & $\$$ \\
\hline ص & 0635 & Sad & $\mathrm{s},(\mathrm{s} \infty)$ & $ص$ & FEB9 & $\infty$ & FEBB & $\infty$ & FEBC & $ص$ & FEBA & S \\
\hline ض & 0636 & Dad & $\mathrm{d},(\mathrm{d} \infty)$ & ض & FEBD & ضـ & FEBF & $\dot{2}$ & FEC0 & ض & FEBE & D \\
\hline b & 0637 & Tah & $\mathrm{t},(\mathrm{t} \infty)$ & $b$ & FEC1 & $b$ & FEC3 & b & FEC4 & b & FEC2 & $\mathrm{T}$ \\
\hline ظ & 0638 & Zah & $\mathrm{z},(\mathrm{z} \infty)$ & ظظ & FEC5 & ظ & FEC7 & $\dot{k}$ & FEC8 & ظ & FEC6 & Z \\
\hline$\varepsilon$ & 0639 & Ain & $\begin{array}{l}\text { Initial: } a, i, u \\
\text { Final: } k,\left({ }^{(}\right)\end{array}$ & $\varepsilon$ & FEC9 & $s$ & FECB & $x$ & FECC & $c$ & FECA & $\mathrm{E}$ \\
\hline$\dot{\varepsilon}$ & $063 \mathrm{~A}$ & Ghain & gh & $\dot{\varepsilon}$ & FECD & $\dot{s}$ & FECF & $\dot{x}$ & FED0 & $i$ & FECE & $\mathrm{g}$ \\
\hline$\dot{\varepsilon}$ & 06A0 & $\begin{array}{c}\text { Ain with } \\
\text { three dots } \\
\text { above }\end{array}$ & ng & & & & & & & & & $\mathrm{e}$ \\
\hline ف & 0641 & Feh & $\mathrm{f}$ & i & FED1 & $\dot{2}$ & FED3 & $\dot{i}$ & FED4 & فن & FED2 & $\mathrm{f}$ \\
\hline ث & 06A4 & Veh & $\mathrm{p}$ & ث & FB6A & ثे & FB6C & $\hat{\imath}$ & FB6D & ق & FB6B & V \\
\hline ق & 0642 & Qaf & $\mathrm{k}, \mathrm{q},(\mathrm{q})$ & ق & FED5 & ق & FED7 & $\ddot{2}$ & FED8 & ق & FED6 & $q$ \\
\hline s & 06А9 & Kaf & $\mathrm{k}$ & g] & FED9 & 5 & FEDB & $<$ & FEDC & ل & FEDA & $\mathrm{k}$ \\
\hline ت & 0762 & $\begin{array}{l}\text { Kaf with dot } \\
\text { above }\end{array}$ & $\mathrm{g}$ & & & & & & & & & Q \\
\hline J & 0644 & Lam & 1 & $J$ & FEDD & 1 & FEEF & $\lambda$ & FEE0 & J & FEDE & 1 \\
\hline s & 0645 & Meem & $\mathrm{m}$ & $p$ & FEE1 & s & FEE3 & a & FEE4 & r & FEE2 & $\mathrm{m}$ \\
\hline ن ن & 0646 & Noon & $\mathrm{n}$ & ن & FEE5 & ; & FEE7 & $\therefore$ & FEE8 & ن & FEE6 & $\mathrm{n}$ \\
\hline 。 & 0647 & Heh & $\mathrm{h}$ & • & FEE9 & $D$ & FEEB & $t$ & FEEC & $d$ & FEEA & $\mathrm{h}$ \\
\hline g & 0648 & Waw & $\mathrm{w}, \mathrm{u}, \mathrm{o}$ & و & FEED & & & & & g & FEEE & w \\
\hline ف & $06 \mathrm{CF}$ & $\begin{array}{l}\text { Waw with } \\
\text { Dot Above }\end{array}$ & $\mathrm{v}$ & & & & & & & & & W \\
\hline ي & 064A & Yeh & $\mathrm{y}, \mathrm{i}$, e taling & ي & FEF1 & 2 & FEF3 & $\tilde{*}$ & FEF4 & ي & FEF2 & $\mathrm{y}$ \\
\hline ى & 0649 & $\begin{array}{c}\text { Alef } \\
\text { Maksura }\end{array}$ & final e pepet & $\checkmark$ & FEEF & & & & & $s$ & FEF0 & $\mathrm{Y}$ \\
\hline 3 & 06BD & $\begin{array}{l}\text { Noon with } \\
\text { three dots } \\
\text { above }\end{array}$ & ny & & & & & & & & & $X$ \\
\hline$=$ & 0621 & Hamza & $\begin{array}{l}\text { Initial: drop } \\
\text { Final: } k,\left(^{(}\right)\end{array}$ & \& & FE80 & & & & & & & , \\
\hline i & 0623 & $\begin{array}{l}\text { Alef, Hamza } \\
\text { above }\end{array}$ & - & $i$ & FE83 & & & & & $i$ & FE84 & $>$ \\
\hline$!$ & 0625 & $\begin{array}{l}\text { Alef, Hamza } \\
\text { Below }\end{array}$ & - & $!$ & FE87 & & & & & $!$ & FE88 & $<$ \\
\hline ئ & 0626 & $\begin{array}{c}\text { Yeh, Hamza } \\
\text { above }\end{array}$ & - & s & FE89 & i & FE8B & 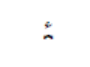 & FE8C & s & FE8A & \} \\
\hline$r$ & 0662 & $\begin{array}{c}\text { Indic Digit } \\
\text { Two }\end{array}$ & - & & & & & & & & & 2 \\
\hline
\end{tabular}

The next phase in natural language text preparation is tokenization, which typically plays an important role in cutting a string into identifiable units that constitute a piece of language data (Bird, Klein, \& Loper, 2009). The simplest method commonly used in tokenizing a text is to split it on whitespace. Although this is the fundamental task in NLP, Jawi script is still far from having a standard tokenizer. At present, there is no sufficiently comprehensive, well-designed standard corpus that is annotated and publicly available for the 
Jawi script corpora. Tokenization task is chosen to evaluate the significance of the corpus because of the Buckwalter transliteration format applied to Jawi characters. Further explanation is made on the NUWT Corpora Evaluation.

\section{Corpus Annotation}

POS annotation (also morpho-syntactic annotation) consists of assigning each word in a corpus to its general word-class (e.g., nouns), or to finer-grained grammatical categories (e.g., singular common noun) (Balossi, 2014). It also enables the tagging of homographs; for example, the term 'work' can be tagged as a verb or as a noun. Semantic annotation marks the semantic categories of words in a text; for example, the term 'bank' can belong to two different semantic fields according to whether it refers to a financial institution or an area of land along a river. Through lexical annotation, we learn about the lemma - the base form of a word - of each word form in our corpus; for example, 'speak', 'speaks', 'spoke, 'speaking' are forms of the same lexeme, with 'speak' as their lemma. Pragmatic annotation adds information to the words and multi-word expressions in a spoken conversation or dialogue; so the expression 'go now' may become a command or a question depending on the punctuation marks used. Linguistic annotation is used to capture a range of higher-level phenomena, including the practice of tagging the types of speech and thought presentation (e.g., direct speech and indirect speech, direct thought and indirect thought, etc.). On the use of corpus annotation, Leech (2005) states that "the practice of adding interpretative linguistic information to a corpus" confers an "added value" to it. An annotated corpus has the advantage of being used in either a "manual examination" or in an "automatic analysis". Moreover, it can be re-used and exploited for different aims and applications.

Both the Malay corpus and the Malay corpus UKM-DBP were developed according to the DBP tagset. General word-class has been used for both corpora. The Malay tagged corpus has been developed with the same tagset used in the modified bilingual dictionary (Hock, 2009) as stated in Mohamed et al. (2011). Some tags have not been used in the corpus, while a few new ones have been added. The AWL and KEP tags, which are linguistically not word classes, have not been used in the corpus. Other than that, clitics in Malay, such as nya (it, them), $m u$ (you), lah (a particle added to words (suffix) used for emphasizing its predecessor word or sentence), kah (a particle at the end of a word or phrase for expressing enquiry), etc., are crucial to the Malay language. In the Malay corpus, only two clitics are handled, whereby the clitic, nya and lah are split into two tokens. For example, the word terjejasnya (it being affected) is split into terjejas (is affected) and nya (it). Thus, the tag @ $\mathrm{KG}$ is used to tag nya, and \# $\mathrm{E}$ for tagging lah (Mohamed et al., 2011). Other 
added tags have also been used, such as KNF to tag denial words, KNK to tag proper nouns, SEN to tag any list numbers, and SYM to tag any symbols, including punctuations. In the NUWT Corpora, each tag used in the original corpus is maintained and the use of ASCII letter is also maintained as in the original corpus. Figures 6,7 and 8 show the sample data of three corpus in the NUWT Corpus.

...1.1 den nAm Allh ye Vmwrh dAn VXAye

... (1.1 Dengan nama Allah yang Maha Pemurah dan Penyayang)

Gloss: In the name of Allah, the Beneficient, the Merciful

...1,2 sQnV Vwjyn Awntwq Allh , twhn smstA EAlm...

... (1,2 Segenap pujian untuk Allah, tuhan semesta Alam...)

Gloss: All praise is due to Allah, the Lord of the Worlds ...

Figure 6. The Quranic Malay written in the Jawi character corpus.

... nAmwn sAyA mndAVt ...

KH KG KK

...(namun saya mendapat ...)

KH $\quad K G \quad K K$

Gloss: but I get ...

...dAVt mewrekn ms \}lh2 sVrty...

KB KK KN KSN

... (dapat mengurangkan masalah-masalah seperti ...)

$\begin{array}{llll}K B & K K & K N & K S N\end{array}$

Gloss: may reduce problems such as ...

Figure 7. The Malay corpus.

... rAVt $\mathrm{s}>$ wlh Vty-kArwn tq ...

A NAK

... (rapat seolah peti-karun tq ...)

A NAK

Gloss: close like a treasure chest not ...

... EAlm AdAlh ktAb trbwk...

NAK NAK VTT

... (Alam adalah kitab terbuka ...)

NAK NAK VTT

Gloss: Nature is an open book ...

Figure 8 . The Malay UKM-DBP corpus. 


\section{NUWT CORPORA EVALUATION}

To evaluate the new corpus, previous researchers (Outahajala, Zenkouar, Benajiba, Rosso, \& Elirf, 2013; Tmshkina, 2006) have used or applied the new corpus to the state-of-the-art POS tagger, such as TnT, Support Vector Machine (SVM) and Conditional Random Field (CRF). Accuracy (\%) has been used to measure the performance of the corpus. However, in this study, a new orthography is used, which is the Jawi-specific Buckwalter transliteration, which is tagged along with the previous known tag set. Thus, it is believed that the tokenizer task is a suitable task for the evaluation of the corpora because of its orthographical differences with the Malay language written in Roman.

As a pilot study, the application of the NUWT corpus to a tokenization task was made to reveal what modifications are needed. The NLTK was used which is a platform for building Python programs to work with human language data. The NLTK is easy to use and interfaces with over 50 corpora and lexical resources, such as WordNet, and has a suite of text processing libraries for classification, tokenization, stemming, tagging, parsing and semantic reasoning (NLTK Project, 2015). There are several types of tokenizers in NLTK, which are Punkt Sentence Tokenizer, Regular Expression Tokenizer, S-Expression Tokenizer, Simple Tokenizer, Penn Treebank Tokenizer and NLTK Tokenizer package. In our experiment, we used the regular expression tokenizer module from NLTK for the Jawi corpus. The regular expression tokenizer is deemed suitable for this task because of its uniqueness in handling language-dependent applications and algorithms (Shaalan \& Raza, 2007; Sharum, Abdullah, Sulaiman, Murad, \& Hamzah, 2011).

\section{Jawi Regular-Expression Tokenizer (Jawi RegExpTokenizer)}

A RegExpTokenizer splits substrings using a regular expression. A tokenizer then matches either the tokens or the separators between tokens. The tokenizer tokenizes a string, treating any sequence of blank lines as a delimiter. Blank lines are defined as lines containing no characters, except for space or tab characters (NLTK Project, 2015). The NLTK's regular expression tokenizer uses four parameters.

- $\quad$ pattern (str) - The pattern used to build this tokenizer. This pattern may safely contain capturing parentheses.

- $\quad$ gaps (bool) - True if this tokenizer's pattern should be used to find separators between tokens; False if this tokenizer's pattern should be used to find the tokens themselves.

- discard_empty (bool) - True if any empty tokens generated by the tokenizer should be discarded. Empty tokens can only be generated if _gaps $==$ True. 
- $\quad$ flags (int) - The regular expression flags used to compile this tokenizer's pattern. By default, the following flags are used: re.UNICODE | re.MULTILINE | re.DOTALL

Jawi-specific extension Buckwalter character code is normally not very different from English character code. By default, abbreviation patterns,

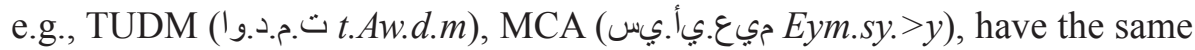
pattern or writing style as the English language, e.g., U.S.A. The abbreviations and acronyms in the Malay language are shown in Table 7 (Abdul Rahman, 1999; DBP, 2008). Arabic characters have no distinct uppercase and lowercase letter forms when writing abbreviations and acronyms.

Table 7

Writing Abbreviations and Acronyms for Jawi and Roman in Malay Language

\begin{tabular}{|c|c|c|c|}
\hline No & Form & Roman & Jawi \\
\hline 1. & $\begin{array}{l}\text { Special name; name of the position, rank, title, and proper } \\
\text { name. }\end{array}$ & Profesor & روسيفورث \\
\hline 2. & $\begin{array}{l}\text { Initial abbreviation for the name of department and the } \\
\text { position of the Malay language. }\end{array}$ & TUDM & ت.م.د.وا \\
\hline 3. & $\begin{array}{l}\text { Initial abbreviation for the name of the department and the } \\
\text { position of the English language. }\end{array}$ & $\mathrm{MCA}$ & ميع.ئ.بس \\
\hline 4. & Acronyms special name / common in Malay / English & Pas & 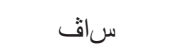 \\
\hline
\end{tabular}

Patterns 1, 2, 3, 11, 12 and 13 (non-highlighted table) are common in the English language (refer to Table 8). Patterns 4-10 (highlighted table) are new patterns matching the Jawi corpus. If the pattern detects any punctuation marks, such as periods (.), commas (,), semicolons (;), colons (:), parentheses (), dashes (-), exclamation points (!), quotation marks (") or underscores ( $)$, the tokenizer will automatically segment the word into two separate words. Otherwise, the tokenizer will leave it as a single word. Patterns, such as $* \dot{j}$, $\$ \dot{\omega},>\{,<$, and $\}$ are supposed to be segmented as a single word when it occurs in the raw text or sentence. Patterns identified as a single or a separate word in Malay in the Jawi character are shown in Table 8. Regular expression patterns are sorted by priority. If a standard tokenizer built for other languages is used, such as the English language, patterns, such as $*,>,<$,$\} , will be$ segmented into two separate tokens. In the Arabic language, the orthographic problem interferes, as we have mentioned above. 
Table 8

Tokenization Pattern for Jawi

\begin{tabular}{clc}
\hline No & Pattern & Segment taken \\
\hline 1. & Abbreviation, e.g., U.S.A & Single token \\
2. & Cardinal number, e.g., 1.1 & Single token \\
3. & Words with internal hyphens, e.g., Anq-Anq, i.e., children & Single token \\
4. & Words with an asterisk (*) symbol (represent Thal (ذ)) & Single token \\
5. & Words with a Dollar sign symbol \$ (represent Syin (ش)) & Single token \\
6. & Words with > sign symbol (represent letter alef with hamza above (أ)) & Single token \\
7. & Words with < sign symbol (represent letter alef with hamza below (!)) & Single token \\
8. & Words with \} sign symbol (represent letter yeh with hamza above (s)) & Single token \\
9. & Words with Malaysian currency (RM) & Single token \\
10. & Single words other than the cases above & Single token \\
11. & Words with percentage (\%) & Single token \\
12. & Ellipsis, e.g., ... & Single token \\
13. & Any punctuation mark, such as .,,"?():-_! & Separate token \\
\hline
\end{tabular}

\section{Algorithm and Implementation}

The tokenizer process is summarized as per the following algorithm:

The following algorithm, PatternMatching, constructs tokens using regular expression

Require: text T, pattern P, gaps G,discard_empty D, flags F

begin

read sequence of $\mathrm{T}$,

read regular expression pattern $\mathrm{P}$,

Pattern_Type1 : Abbreviation,

Pattern_Type2 : Cardinal numbers,

Pattern_Type3 : Hyphens

Pattern_Type4 : Ellipsis

Pattern_Type5 : Special character

$* \$<>$ \}'RM'

Pattern_Type6 : Punctuation marks

read gaps G,read discard_empty D,

read flags $\mathrm{F}$,

If found regular expression pattern $\mathrm{P}$ in sequence of $\mathrm{T}$

single token

else

separate token

applied gaps G, discard_empty D,

flags $\mathrm{F}$

end 


\section{Tokenizer Experiments}

The experiments outlined in this paper were tested using the bootstrapping approach and started with a few training words, 1,000, 5,000, 10,000 and 15,000 words for each corpus. A series of experiments were performed. Our first experiment was to manipulate a standard regular expression tokenizer built for the English language. One of the issues in tokenizing English words is the presence of contractions, such as didn't. In the NUWT Corpora, the apostrophe symbol (') represents the letter Hamza (c). Other than that, the English language uses uppercase letters to identify abbreviations; meanwhile, in our corpora, the uppercase and lowercase letters for the abbreviations were used.

For the first implementation, the regular expression pattern suitable for Jawispecific Buckwalter code was built up. The errors obtained from the first experiment were with a minimum error of 0.01038961 , a maximum error of 0.029490617 and an average error of 0.020255 . Several errors were obtained from a number of issues, as listed in Table 9.

\section{Table 9}

Errors from Certain Issues

Error Action taken $\begin{gathered}\text { Action that } \\ \text { should have been } \\ \text { taken }\end{gathered}$

\begin{tabular}{|c|c|c|}
\hline $\begin{array}{l}\text { Words with asterisk }(*) \text { symbol, representing the letter } \\
\text { Thal (ذ) }\end{array}$ & Missing word & Single word \\
\hline $\begin{array}{l}\text { Words with Dollar (\$) sign, representing the letter } \\
\text { Sheen (ش) }\end{array}$ & Separate word & Single word \\
\hline $\begin{array}{l}\text { Words with > sign symbol, representing the letter alef } \\
\text { with hamza above (I) }\end{array}$ & Missing word & Single word \\
\hline $\begin{array}{l}\text { Words with }<\text { sign symbol, representing the letter alef } \\
\text { with hamza below (I) }\end{array}$ & Missing word & Single word \\
\hline $\begin{array}{l}\text { Words with \} sign symbol, representing the letter yeh } \\
\text { with hamza above (ئ) }\end{array}$ & Missing word & Single word \\
\hline Words with Malaysian currency (RM) & Separate word & Single word \\
\hline Punctuation marks (.) & Single word & Separate word \\
\hline
\end{tabular}


For example, the $* \dot{\text { }}$ (Thal) character can be seen in the front, middle, and final position of a word in Table 10. During the first experiment, only Thal in the middle position could be detected as a single word. However, Thal in the front and final part of the words is missing. See Figures 9, 10 and 11. Fig. 12 shows the error rate $(\%)$ for the NUWT corpus.

Table 10.

* j (Thal) in the Word

\begin{tabular}{ccc}
\hline Jawi & Transliteration & Gloss \\
\hline \multirow{2}{*}{ ذاتسا } & *wryt & Offspring \\
ذباذع & AstA* & Teacher \\
\hline
\end{tabular}

Input: ttAVy kwAs Allh ye Ayeyn mmbry *wryp

Jawi: تتاثي كو اس اله يخ ايغين ممبري ذورية

Gloss: but the power of Allah to give offspring

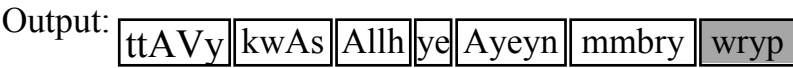

Figure 9. Error in program (First letter Thal ذ).

Input: kAlAw stAkt jAdy AstA* AtAw AmAm msjd Jawi: كالاو ستاكت جادي استاذ اناو امام مسجد

Gloss: if only become teacher or imam of the mosque

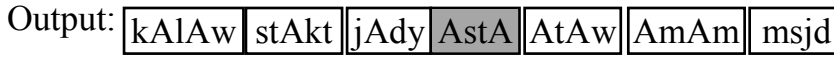

Figure 10. Error in program (Last letter Thal ذ).

Input: dAn Awntwq mryk syqsA'n ( $E^{*} A b$ ) ye Vdyh

Jawi: دان اونتوف مريك سيقساءن (عذاب) يخ ثديه

Gloss: and there is a great punishment

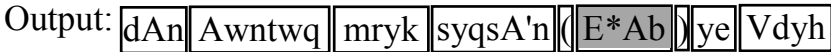

Figure 11. Middle letter Thal $\dot{j}$ detected the same as the input. 


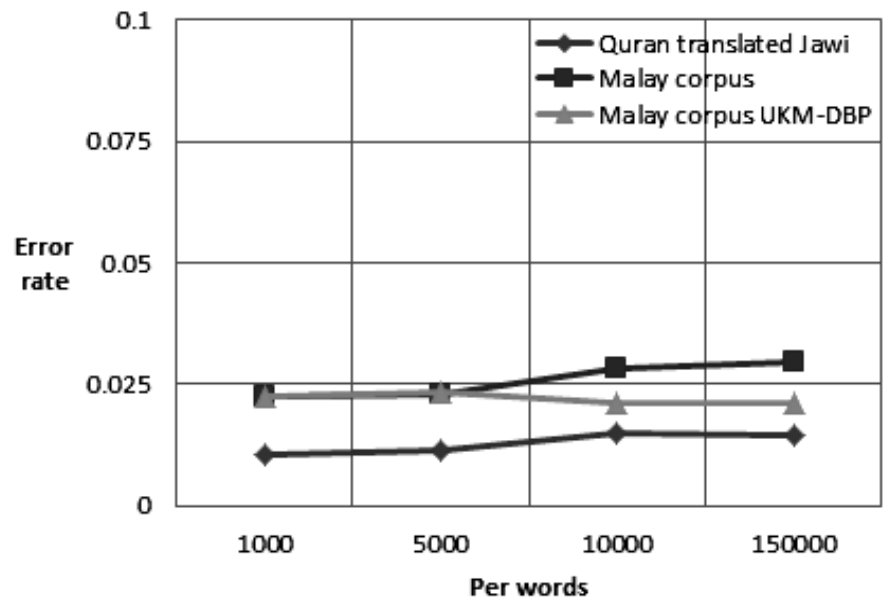

Figure 12. Error rate (\%) for NUWT corpus.

After several modifications were made to the program's code, these errors were addressed. The second experiment shows the complete performance of the tokenization on the NUWT Corpora. The accuracy obtained was approximately $99.8 \%$. For example, Figures 13 and 14 show the correct tokenizer word for Error 1. The output overcame the errors which occurred in the program for the same sentences (see Figures 9 and 10). The summary of successful tasks is shown in Table 11.

Input: ttAVy kwAs Allh ye Ayeyn mmbry *wryp

Jawi: تتافي كو اس الله يخ ايغين ممبري ذورية

Gloss: but the power of Allah to give offspring

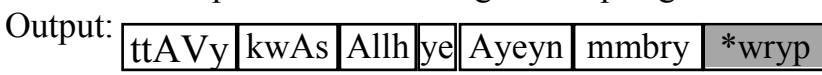

Figure 13. First letter Thal $\dot{j}$ detected the same as the input.

Input: kAlAw stAkt jAdy AstA* AtAw AmAm msjd.

Jawi: كالاو ستاكت جادي استاذ اتاو امام مسجد

Gloss: if only become teacher or imam of the mosque

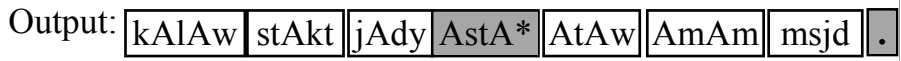

Figure 14. Last letter Thal $\dot{j}$ detected the same as the input. 
Table 11

Successful Tasks

\begin{tabular}{|c|c|c|}
\hline Error & $\begin{array}{c}\text { Action } \\
\text { taken }\end{array}$ & $\begin{array}{l}\text { Action that should } \\
\text { have been taken }\end{array}$ \\
\hline $\begin{array}{l}\text { Words with asterisk }(*) \text { symbol, representing the letter } \\
\text { Thal (ذ) }\end{array}$ & Single word & Single word \\
\hline $\begin{array}{l}\text { Words with Dollar (\$) sign, representing the letter Sheen } \\
\text { (ش) }\end{array}$ & Single word & Single word \\
\hline $\begin{array}{l}\text { Words with > sign symbol, representing the letter alef } \\
\text { with hamza above (I) }\end{array}$ & Single word & Single word \\
\hline $\begin{array}{l}\text { Words with }<\text { sign symbol, representing the letter alef with } \\
\text { hamza below (!) }\end{array}$ & Single word & Single word \\
\hline $\begin{array}{l}\text { Words with \} sign symbol, representing the letter yeh } \\
\text { with hamza above (s) }\end{array}$ & Single word & Single word \\
\hline Words with Malaysian currency (RM) & Single word & Single word \\
\hline Punctuation marks (.) & Separate word & Separate word \\
\hline
\end{tabular}

\section{CONCLUSION AND FUTURE WORK}

A corpora that contains three Malay subcorpora is described in this paper. This corpora is unique due to the code applied. This corpora will serve as a benchmarking corpus for the development and evaluation systems in word tokenization, as well as further language processing. A pilot study successfully developed a tokenizer system to reveal what modifications need to be made in the NUWT Corpora. We attempted to develop the tokenizer model for the NUWT Corpora using regular expression. The aim of this model is to suit the new corpora developed for the Malay language. Based on the experimental results and analysis, it can be concluded that regular expression is appropriate as a Jawi tokenizer in a Buckwalter transliteration format. Further works should focus on Out-Of-Vocabulary (OOV) problem in the POS tagging which is an important text analysis task that is used to classify words into their parts of speech. It labels them according to their tagsets, which is a collection of tags used for POS tagging.

\section{ACKNOWLEDGMENTS}

The first author is funded under the Skim Latihan Akademik IPTA-UUM (SLAI) by the Ministry of Higher Education Malaysia. We would like to thank Dr. Suliana Sulaiman (Sulaiman, 2013), Dr. Hassan Mohamed (Mohamed et 
al., 2011) and Ms. Nurul Huda Mohd Saad (Saad et al., 2012) for the corpus. This material is based on work supported by the Universiti Kebangsaan Malaysia (UKM) under Grant No. ERGS/1/2013/ICT1/UKM/3/5.

\section{REFERENCES}

Abdul Ghani, R., Zakaria, M. S., \& Omar, K. (2009). Jawi-Malay Transliteration. In International Conference on Electrical Engineering and Informatics 2009 (ICEEI'09) (Volume:01) (pp. 154-157). Selangor: IEEE. doi:10.1109/ICEEI.2009.5254799

Abdul Rahman, H. (1999). Panduan menulis dan mengeja Jawi. Kuala Lumpur: Dewan Bahasa dan Pustaka.

Abdullah, I.-H., Hashim, R. S., \& Mohamed Husin, N. (2011). Lexical associations of Malayness in Hikayat Abdullah: A collocational analysis. Research Journal of Applied Sciences, 5(6), 429-433.

Abu Bakar, J. (2008). Transliterasi Jawi Lama-Jawi Baru berasaskan Grafem (Kajian Kes Hikayat Merong Mahawangsa) (Unpublished master's thesis). Universiti Kebangsaan Malaysia.

Ahmad, C. W. S. B. C. W., Omar, K., Nasrudin, M. F., Murah, M. Z., \& Azmi, S. M. (2013). Machine transliteration for old Malay manuscript. In 2nd International Conference on Machine Learning and Computer Science (IMLCS’2013) (pp. 23-26). Kuala Lumpur.

Ahmad, C. W. S. C. W. (2007). Penterjemah Jawi lama kepada Jawi baru (Unpublished master's thesis). Universiti Kebangsaan Malaysia.

Atwell, E. (2008). Development of tag sets for part-of-speech tagging. In A. Ludeling \& M. Kyto (Eds.), Corpus linguistics: An international handbook Volume 1 (pp. 501-526). Walter de Gruyter. Retrieved from http://eprints.whiterose.ac.uk/81781/

Azmi, M. S. (2013). Fitur baharu dari kombinasi geometri segitiga dan pengezonan utk paleografi Jawi digital.

Bakar, J. A., Omar, K., Nasrudin, M. F., Murah, M. Z., \& Ahmad, C. W. S. C. W. (2013). Implementation of Buckwalter transliteration to Malay corpora. In 13th International Conference on Intelligent System Design and Applications (ISDA'13) (pp. 214-218). Serdang, Selangor: Mirlabs. 
Balossi, G. (2014). A corpus linguistic approach to literary language and characterization: Virginia Woolf's the waves. John Benjamins Publishing Company.

Bird, S., Klein, E., \& Loper, E. (2009). Natural language processing with python (1st ed.). USA: O'Reilly Media, Inc.

Buckwalter, T. (2002). Buckwalter Arabic morphological analyzer version 1.0. linguistic data consortium. Retrieved from https://catalog.ldc. upenn.edu/LDC2002L49

DBP. (2008). Daftar kata Bahasa Melayu Rumi-Sebutan-Jawi. Dlm. Dahaman \& M. Ahmad (Eds.) (Kedua.). Kuala Lumpur: Dawama.

DBP. (2015). Pusat Rujukan Persuratan Melayu. Retrieved from http://prpm. dbp.gov.my/

Diab, M., Hacioglu, K., \& Jurafsky, D. (2004). Automatic tagging of Arabic text:From raw text to base phrase chunks. In HLT-NAACL-Short '04 Proceedings of HLT-NAACL 2004: Short Papers (pp. 149-152). Stroudsburg, PA, USA: Association for Computational Linguistics.

Diah, N. M., Ismail, M., Ahmad, S., \& Abdullah, S. A. S. S. (2010). Jawi on mobile devices with Jawi WordSearch game application. In 2010 International Conference on Science and Social Research (CSSR 2010) (pp. 326-329). Kuala Lumpur, Malaysia: IEEE. doi:10.1109/ CSSR.2010.5773793

Diah, N. M., Ismail, M., Hami, P. M. A., \& Ahmad, S. (2011). Assisted JawiWriting (AJaW) Software for children. In 2011 IEEE Conference on Open Systems (ICOS2011) (pp. 322-326). Langkawi: IEEE. doi:10.1109/ICOS.2011.6079260

Dukes, K., \& Habash, N. (2010). Morphological annotation of Quranic Arabic. In Language Resources and Evaluation Conference (LREC) (pp. 2530-2536). Valletta, Malta: ELRA.

Habash, N., \& Metsky, H. (2008). Automatic learning of morphological variations for handling out-of-vocabulary terms in Urdu-English machine translation. In Proceedings of the Association for Machine Translation in the Americas (AMTA-08). Waikiki, Hawai'i. 
Habash, N., Soudi, A., \& Buckwalter, T. (2007). On Arabic transliteration. In A. Soudi, A. van den Bosch, \& G. Neumann (Eds.), Arabic computational morphology: Knowledge-based and Empirical Methods. Springer.

Heryanto, A., Nasrudin, M. F., \& Omar, K. (2008). Offline Jawi Handwritten recognizer using hybrid artificial neural networks and dynamic programming. In International Symposium on Information Technology, 2008 (ITSim 2008) (Volume:2) (pp. 1-6). Kuala Lumpur: IEEE. doi:10.1109/ITSIM.2008.4631722

Hock, O. Y. (2009). Kamus dwibahasa. Petaling Jaya: Pearson Longman.

Irvine, A., Weese, J., \& Callison-Burch, C. (2012). Processing informal, romanized Pakistani text messages. In Proceedings of the 2012 Workshop on Language in Social Media (LSM 2012) (pp. 75-78). Association for Computational Linguistics.

Ismail, K., Yusof, R. J. R., \& Jomhari, N. (2010). A case study of Jawi Editor in the XO-laptop simulated environment. In 2010 International Conference on User Science and Engineering (i-USEr) (pp. 21-25). Shah Alam: IEEE. doi:10.1109/IUSER.2010.5716716

Knowles, G., \& Don, Z. M. (2003). Tagging a corpus of Malay texts, and coping with "syntactic drift." In Proceedings of the corpus linguistics (pp. 422-428). Retrieved from http://eprints.lancs.ac.uk/8620/

Leech, G. (2005). Adding linguistic annotation. In M. Wynne (Ed.), Developing linguistic corpora: A Guide to good practice (pp. 17-29). Oxford: Oxbow Books for the Arts and Humanities Data Service. Retrieved from http://www.ahds.ac.uk/creating/guides/linguistic-corpora/chapter2.htm

Mohamed, H., Omar, N., \& Ab Aziz, M. J. (2011). Statistical Malay Partof-Speech (POS) tagger using hidden Markov approach. In 2011 International Conference on Semantic Technology and Information Retrieval (pp. 231-236). IEEE.

NLTK Project. (2015). NLTK corpora. Retrieved from http://www.nltk.org/ nltk_data

Noor, N. K. M., Noah, S. A., Aziz, M. J. A., \& Hamzah, M. P. (2010). Anaphora resolution of Malay text: Issues and proposed solution model. 2010 International Conference on Asian Language Processing, 174-177. doi:10.1109/IALP.2010.80 
Outahajala, M., Zenkouar, L., Benajiba, Y., Rosso, P., \& Elirf. (2013). The development of a fine grained class set for amazigh POS tagging. In ACS International Conference on. IEEE Computer Systems and Applications (AICCSA) (pp. 1-8). IEEE.

Pasha, A., Al-Badrashiny, M., Diab, M., Kholy, A. El, Eskander, R., Habash, N., .. Roth, R. M. (2014). MADAMIRA : A fast, comprehensive tool for morphological analysis and disambiguation of Arabic. In Proceedings of the Language Resources and Evaluation Conference (LREC) (pp. 1094-1101). Reykjavik, Iceland.

Rahman, S. A., \& Omar, N. (2013). Transforming noun phrase structure form into rules to detect compound nouns in Malay sentences. Journal of ICT, 12, 161-173.

Rahman, S. A., Omar, N., \& Aziz, M. J. A. (2011). A fundamental study on detecting head modifier noun phrases in Malay sentence. In 2011 International Conference on Semantic Technology and Information Retrieval (pp. 255-259). Putrajaya: IEEE. doi:10.1109/ STAIR.2011.5995798

Rahman, S. A., Omar, N. B., Mohamed, H., Juzaidin, M., \& Aziz, A. (2011). A synonym contextual-based process for handling word similarity in Malay sentence.

Redika, R., Omar, K., \& Nasrudin, M. F. (2008). Handwritten Jawi words recognition using hidden Markov models. In International Symposium on Information Technology, 2008 (ITSim 2008) (Volume:2) (pp. 1-5). Kuala Lumpur: IEEE. doi:10.1109/ITSIM.2008.4631723

Saad, N. H. M., Bakar, J. A., Karim, R. A., Tukiman, N., \& Nor, K. M. (2012). Pembangunan korpus cerpen bertag Bahasa Melayu: Analisis linguistik korpora. In Research, Invention, Innovation \& Design (RIID 2012). Universiti Teknologi MARA Kampus Melaka.

SEAlang Projects. (2011). Retrieved from http://sealang.net/malay/dictionary. htm

Shaalan, K., \& Raza, H. (2007). Person name entity recognition for Arabic. In Proceedings of the 2007 Workshop on Computational Approaches to Semitic Languages: Common Issues and Resources (pp. 17-24). Stroudsburg, PA, USA. 
Sharum, M. Y., Abdullah, M. T., Sulaiman, M. N., Murad, M. A. A., \& Hamzah, Z. A. Z. (2011). Name extraction for unstructured Malay text. 2011 IEEE Symposium on Computers \& Informatics, 787-791. doi:10.1109/ISCI.2011.5959017

Sulaiman, S. (2013). Pencantas perkataan Melayu untuk aksara Jawi berasaskan petua. Bangi: Universiti Kebangsaan Malaysia.

Sulaiman, S., Omar, K., Omar, N., Murah, M. Z., \& Abdul Rahman, H. (2014). The effectiveness of a Jawi stemmer for retrieving relevant Malay documents in Jawi characters. ACM Transactions on Asian Language Information Processing, 13(2), 6.

Sulaiman, S., Omar, K., Omar, N., Murah, M. Z., \& Rahman, H. A. (2011). A Malay stemmer for Jawi characters. In D. Wang \& M. Reynolds (Eds.), AI 2011: Advances in Artificial Intelligence (pp. 668-676). Perth, Australia: Springer Berlin / Heidelberg.

Tmshkina, J. (2006). Development of a multilingual parallel corpus and a part-of-speech tagger for Afrikaans. IFIP International Federation for Information Processing, 228, 453-462.

Unicode. (2014). Unicode. Retrieved from http://unicode.org

Yonhendri. (2008). Enjin transliterasi rumi Jawi (Unpublished master's thesis). Universiti Kebangsaan Malaysia. 